\title{
Beyond Ballotocracy: Citizens' Voices and the Many Faces of Unruly Politics
}

\author{
Mariz Tadros
}

\begin{abstract}
This article is an empirical account of how modes of capturing citizen voices from above (via elections) diverged with expressions of citizen dissidence from below (through unruly politics), leading to a disjuncture between Western policy and scholarly analyses and the situation on the ground in post-Mubarak Egypt in the period 2011-13. The article does not suggest the abandonment of elections as a means of capturing citizen voices but unless elections are complemented with other measures that capture the changing 'citizen pulse' across different times and spaces, disconnects between what is happening on the ground in Egypt and international and national policy will grow, with the outcome of growing violence and loss of human lives. The article argues that attempts to methodologically capture the 'pulse of citizens' must be sensitive to its dynamic nature (requiring constant revision and verification) and sensitive to the highly specific contextual nature of its expression and decryption.
\end{abstract}

\section{The limits of ballotocracy}

The ousting of President Mubarak in February 2011, after 18 days of protest, held promise at the time of a democratic transition that would fulfil people's aspirations for 'bread, freedom and social justice/dignity', a catchcry of the January revolution. At a time of extreme political volatility, there was very little consensus between the various political forces that instigated the revolts and the elites who came to power thereafter about how democratisation should be pursued. Leading international democratisation scholars' engagement with the post-Mubarak Egyptian scenario was the importance of the instatement of liberal procedural democracy through policies such as drafting a new constitution and holding free and fair presidential and parliamentary elections. These measures, as will be evidenced next, were often spoken of by Western scholars of democracy as both milestones and as 'reality checks' on how a country is progressing.

Elections in particular were treated by many Western scholars and analysts as the channels for citizen participation, expression of voice and as the terrain through which battles for citizen voices were won, even though the broader academic literature on democratisation recognises a more holistic understanding of democracy in its substantive forms (such as Fung and Wright 2003; Gaventa 2003; O’Donnell 2010).

Egypt held its first post-Mubarak parliamentary elections in December 2011/January 2012, and witnessed a sweeping victory of Islamist political parties (parties which endorse a state fully compliant with Islamic Sharia law). The Muslim Brotherhood, a religious-political movement founded in 1928, won 47 per cent of the seats, while ultra-conservative Islamist groups won another 25 per cent of the seats. The presidential elections which took place in June 2012 saw the Muslim Brotherhood's candidate Mohamed Morsi winning over a former air force general Ahmed Shafiq by a very slim margin of 3 per cent (51.7 per cent versus 48.3 per cent).

However, if one takes into account the election turnout, it becomes clear that the level of public endorsement for the Muslim Brotherhood in absolute terms had decreased. In the parliamentary elections turnout was 62 per cent; in the presidential elections, it had gone down to 51 per cent. The drop in electoral support should not be taken lightly. It shows that citizens were losing faith in the Muslim Brotherhood even within the space of six months. 
Hence, Morsi's commencement of a new presidential term was not premised on a strong majority. He began his term in office under extreme pressure to deliver on his campaign pledges of more jobs, a cleaner environment, strengthening security and prosperity to be enjoyed by all Egyptians. Signs of growing dissent among the citizens began to appear soon in the form of frequent and well-attended protests, demonstrations, marches and sit-ins to protest against political repression, economic need and unmet promises. One year into office, nonIslamist political parties had also disengaged from participating in Morsi's government and their opposition to heavy-handed security measures (such as on 4 December 2012, in front of the presidential palace) catalysed the formation of a counter-coalition front comprising youth revolutionary forces, political parties, the leadership of Al Azhar (Egypt's highest Sunni Muslim religious authority) and various social movements such as women's organisations and labour groups. The growing level of discontent on the streets manifested itself in daily eruptions of one form or another of street activism after Morsi's first three months in office (which ended in September 2012).

However, many of the leading academics who have political salience in policy spaces continued to focus in 2012-13 almost exclusively on liberal procedural expressions of democratic engagement in the formal arena. Marina Ottaway, who was then a senior member of the Carnegie Endowment for International Peace, an influential thinktank with strong policy links to the US administration, argued at the time that:

The most important step is for secular parties to accept that, if they want a democratic outcome, they have to fight in the electoral arena. Democracy does not just mean elections, though they are an unavoidable component of a democratic process... It is not that Islamists do not share the blame for the present state of affairs. They have become arrogant and overly sure of themselves, but the only way to stop them is to show that they are vulnerable to competition (Ottaway 2013).

It is interesting that she stresses that (electoral) competition is the only way to oppose, resist or hold accountable the authorities in power. As will be shown in the next section, democratic processes were occurring through contestation and resistance rather than competition through the ballot boxes.

Renowned transitologist Alfred Stepan, writing for Freedom House, another major policyinfluencing thinktank, echoed the same sentiment when he argued that:

The prospects for a democratic transition in Egypt would be strengthened if liberal and moderate Islamist forces would reach consensus on the way forward, accept the sovereignty of the Egyptian people, as expressed in elections, and build the institutions needed to ensure that when the elected government takes office, it will uphold the rights of all Egyptian citizens [author's emphasis added] (Stepan 2012).

Stepan's statement suggests that the sovereignty of the Egyptian people is manifested through elections in terms of expression through elections. This narrow focus on elections as a proxy for the power of the people emanates from a particular conception of expression of citizen voice which is oblivious to the multitude of other forms and ways in which citizens express themselves.

Marc Lynch, a professor of political science at George Washington University and editor of Foreign Policy's Middle East page, a publication with significant bearings on policy debates, argued in December 2012 that the playing field for mobilising for democracy is the elections. Here, it is noteworthy, however, that in that same month citizen participation in the constitutional referendum that the Muslim Brotherhood-led government staged in order to pass a constitution that was considered by many political forces in Egypt as exclusionary and in violation of human rights (Tadros 2013), had been as low as 32.9 per cent of eligible voters.

Lynch still believes that the platform for citizen expression of dissent would be a future ballot box: 'The mediocre turnout at the constitutional referendum suggests that they will be punished at the ballot box for these failings - if their political opponents can work effectively to capitalize on the moment' (Lynch 2012).

While many coalitions and political forces spoke of an ongoing revolution to achieve the aims of 
the revolts of January 2011, and believed that the Muslim Brotherhood's legitimacy was on the line (Tadros 2013), Lynch and other Western academics still hung on to the idea that Egypt's transition stands a chance if people can voice their agency through an election. Lynch argued:

But a strong electoral performance by the opposition could also - finally - create meaningful checks on Presidential authority for the first time in modern Egyptian history. The best case here would be that the opposition can build on the energy of its protests, its newfound unity and the strongly felt antipathy towards the Muslim Brotherhood, to compete effectively two months from now in Parliamentary elections. That would position it to legislate more liberal interpretations of the Constitution, and to block any Presidential efforts to impose a more autocratic or more Islamist agenda (Lynch 2012).

Thomas Carothers, a leading democracy expert and vice-president of Carnegie, argued in May 2013, one month prior to the mass uprising that brought down President Morsi's regime, that the highly politically volatile climate often witnessed in post-dictator contexts means that there may be rapid rotation of power as citizens vote one candidate out of office in favour of an alternative. While this comparative dimension is welcomed for more nuanced analysis, it still assumes that citizens will be expressing their voices through the ballot boxes rather than other forms of public expression:

The Brotherhood's strong grassroots network and relative leadership coherence may enable it to become a long-ruling dominant force in post-Mubarak Egypt. Yet in poor countries with few natural resources, like Egypt, whichever political group or party first gains power after the collapse of the dictator inherits the daunting problem of satisfying unrealistically high expectations of citizens for rapid and substantial improvements in their daily lot. Some post-authoritarian countries do settle into dominant-party rule for sustained time periods; yet just as many experience frequent alternations of power as increasingly frustrated voters try one option after another, including parties that initially seemed marginal (Carothers 2013).
Beyond which political party makes an electoral victory, evidence of decreasing citizen turnout in referendums and elections in 2012 should have been an important indicator to analysts that citizens may not necessarily be expressing their voices through the ballot boxes. In the following section, I argue that many had chosen other forms of public engagement that should have featured in attempts to capture the pulse of the citizenry.

Moreover, by focusing on what happens in the electoral politics, there was insufficient attention being paid to the possibility that the new government in Egypt would use elections as a democratic mantra for undemocratic purposes. Miller's analysis of political processes following the ousting of authoritarian regimes in subSaharan Africa warned that:

A cautionary lesson can be drawn from the wave of political transitions that in the early to mid-1990s swept through sub-Saharan Africa, a region with nearly as little prior democratic experience as the Arab world. Though overall less tumultuous than the revolutions of the Arab Spring, these transitions occurred relatively quickly and many involved public protests. After the initial swell of change, many of these transitions failed to deliver enduring democratization... newly elected regimes often practiced old forms of repression or manipulated democratic formalities to their benefit (Miller 2012).

Elis Goldberg argued that, against the backdrop of increasing contestation of the Muslim Brotherhood's governance, the practice of elections does not put Egypt on the path of a democratic transition. She suggested that judging from the level of protests, Egypt is very much in the midst of an unfinished revolution. For the Muslim Brotherhood, she contended:

[E]ven a large electoral majority in parliamentary elections may not, for the foreseeable future, translate into viable governance as popular demands continue to be expressed in ways that are both democratic and disruptive and as the political leadership of the country finds it difficult to agree on a common path forward (Goldberg 2013).

Some Egyptian analysts have been more scathing in their critique, arguing against the tyranny of 
the ballotocracy or boxocracy. Amr Ezzat, a renowned blogger reflected:

Once the voting was over, it meant that there were two parties - on the one hand, a triumphant winner who demanded all advantages of power, and on the other, the defeated losers. Ballot box does nothing to guarantee civil freedoms and rights. Ballot box rule encourages the winner to do anything to seize the levers of state power. And on 30 June, the flimsy legitimacy of ballot box rule finally crumbled (Ezzat 2013).

One of the conceptual and methodological limitations of focusing on electoral-procedural dimensions and the formal players in political society is that it fails to take into account the constellation of factors that are key to substantive elements of democracy such as citizenship rights. The mass uprising of June 2013 was unexpected by many analysts and commentators due to its scale (far bigger turnout than that of January 2011) and plurality of citizen profiles (rural as well as urban, disproportionately high representation from women, more governorates from around the country). By focusing almost exclusively on the elections being a proxy for legitimacy, analysts had failed to recognise the growing population expressing their voice through alternative means.

Ezzat (2013), however, also acknowledges that even with the downfall of the Morsi regime, new political orders may seek to reproduce the same attempts at usurping power, monopolising it and legitimising it through the ballot box. He argues that the only backstopper against this happening is in people rising in protest again and again. This is critically important for the current context in Egypt in which El-Sissi, the former Minister of Defence who ousted Morsi has won the presidential elections with an overwhelming majority vote (over 96 per cent). If he does not deliver on the people's aspirations, they will rise again. In a survey of over 2,400 women and men who participated in the 30 June revolts in 2013, over half of them had said in December 2013/January 2014 that their preference would be for El-Sissi as president; however, 79.2 per cent said they would rise again if their aspirations were not met (Tadros 2014a). This is critically important as it suggests that citizens' commitment to expressing their voice is still strong, even three years after the first revolution of 2011. We should not, however, fall into the same pitfalls of analysis by assuming that they will necessarily express any opposition through the next presidential elections in five years' time. Citizens may choose to express their voice through boycotting elections, or engaging in some kind of unruly politics (see Section 2), be it through street activism or through some other context-appropriate means of expressing themselves.

\section{Unruly politics and unorganised public action}

The uprisings that ruptured the status quo in Egypt in 2011 and 2013 challenge us to rethink the mechanisms, the agendas and the actors we associate with social and political activism. Ali (2012) suggested that prior to the January 25th revolution, the protests became so frequent that he could not keep track of them anymore, nor did the press bother to report all of them (Tadros 2012a). Yet these protests were important precursors to the revolution because they served as political incubators for politicised action for many and provided people with the organisational skills needed to act collectively. While these protests were going on, many leading opposition public figures and intellectuals (such as Ibrahim Eissa) were at the time lamenting why Egyptians did not rise up.

Many missed these episodes of public dissent because these forms of collective action did not fit the checklist of what constitutes the right way to challenge the status quo by the right citizenry. When workers, labourers, farmers and Copts (Egyptian Christians) organised protests, these were often shunned as too narrow in their representation and demands. In other words, these protests were not seen as chipping at the status quo. The same dismissive attitude informed many of the analyses of the continued protests by the same groups in Egypt after the revolution. There was an equally derisive response from many of the local intelligentsia towards the tactics deployed to show public dissidence as lacking in a radical edge or a sufficiently forceful assault on the ruling authorities to be of any effect.

Yet in many cases, dissidents were aware that clashes with the security forces would lead to their incarceration and repression, so they found other ways of being disruptive using what 
McAdam, Tarrow and Tilly (2001) would typically call mechanisms of contentious politics. One of the most successful tactics was the 'Stay at Home' campaign launched by one of the youth movements that emerged during Mubarak's reign, the 'April 6 Youth Movement' which in 2008, via Facebook and text messages called upon people not to go to work. The strategy subverted the security apparatus threats against workers who dare to strike or citizens who protest in solidarity. Groups of citizens informed the politicians by making noise with pots and pans that they were hungry. The April 6 Youth Movement raised straw broomsticks in front of the shrine of the Prophet's daughter, at the Sayeda Zeinab district, to signal that the country is in need of a clean-up.

What is significant is that the actors were not the conventional agents of change; they were not civil society organisations, nor social movements, nor political parties - in other words, they were not the conventional actors associated with the development and democratisation policy domains. They could not be neatly compartmentalised into types of civil society organisations because in most cases, they did not have an organisational structure in the first place. It is in this sense that such actors' engagement in unruly politics is so critically important. Unruly politics here is defined as the marginal space through which citizens engage politically outside the conventional realms of state and civil society [emphasis added] (Tadros 2012a). All kinds of actors with progressive and regressive agendas engage in unruly politics, hence the caution against its romanticisation. Irrespective of whether unruly politics achieves its desired outcomes in terms of making the regime more responsive to its demands, its very dynamics as it played out in Egypt during Mubarak's later tenure and the post-Mubarak revolutionary phase suggest that the status quo was being fundamentally shaken to its very fabric.

The significance of unruly politics manifests itself when we examine the political landscape of activism in Egypt prior to the uprisings. Abd el Wahab (2012) shows that civil society in Egypt by and large no longer served as the arena for contestation, except on the fringes (judges' clubs, professional syndicates and workers' independent groups). His analysis suggests that civil society organisations had become too
Table 1 Protests in Egypt by different groups, 2012

\begin{tabular}{lr}
\hline Organiser & Number \\
\hline Government sector & 1,381 \\
Citizens & 1,205 \\
Private sector employees & 410 \\
Public sector workers & 222 \\
Self-employed & 204 \\
\hline Total & 3,422
\end{tabular}

Source ECESR (2013).

orderly, too politically contained for engagement in contentious politics, so much so that when youth wanted to become politically active, they sought other spaces and other mechanisms that are neither institutionalised nor under the auspices of particular organisational umbrellas.

Even after the January 25th revolution of 2011, the focus of political analysis continues to be on the larger protests, initiated by organised visible actors in political society such as the youth revolutionary movements, the Islamist groups, or the opposition parties. However, beyond the preplanned, pre-organised media-appealing major protests that occur on an interval basis, there are small, spontaneous protests regularly taking place at an average estimate of 11 protests a day. Irrespective of their agendas, these forms of citizen engagement in unruly politics represent important signals of public unrest, and they should not be ignored. They reflect one indicator of 'the pulse on the ground' that requires careful examination. Two years after the revolution, the number of everyday protests organised by small groups of citizens has increased but has gone underneath the radar.

The frequency and disparity of protests in 2012 is one of the strongest indicators of the angry pulse of the citizens under the new Muslim

Brotherhood-led government. This is a viable conclusion to arrive at since other factors have remained constant throughout the past two years. For example, the political space to protest has not changed, nor has the level of political mobilisation increased during those last two years. Yet one of the strong variables congruent with the rise in frequency of protests is Morsi's assumption of the presidency in July 2012. There 
were 185 protests in January, 119 in February, 170 in March, 270 in April, 206 in May, 157 in June, after which there is a dramatic leap to 566 in July, 410 in August, 615 in September, 507 in October, 508 in November and 104 in December ${ }^{1}$ (ECESR 2013).

In 2012 there were 3,422 protests witnessed in Egypt across a spectrum of groups within the population.

An analysis of these protests serves to refute a number of government-propagated myths about citizen participation regarding their profile, motives, geographical focus and political orientation. One of the myths is that only the political elites who are disconnected from the rest of the population are protesting, because they do not wish to have a Muslim Brotherhood-led regime, one that has the endorsement of the rest of the population. It is important to note that with the exception of self-employed and private sector employees whose socioeconomic background may cut across classes, the other categories listed in Table 1 are likely to come from the poor and petite bourgeoisie. Hence, these protestors are not the alienated few, they represent constituencies from within the wider population.

The second myth is that protests are essentially a Cairene phenomenon, and beyond the capital citizens have no interest in such street politics. It is true that the largest number of protests were held in Cairo (684); however, it does not represent a substantial percentage of the total (only 10 per cent) in 2012. The Delta governorates combined witnessed more protests than Cairo (Al Gharbiyya 282, Alexandria 232, Al Sharqiyya 222, Al Dakhaliyya 182). There were also 130 and 212 protests in the Upper Egyptian governorates of Asiut and Minya respectively. Kaft el Sheikh witnessed 161 protests, with the remaining protests occurring in Qalubiyya, Ismailiya and Fayoum combined.

The third widely propagated myth is the notion that these protests were organised by secular anti-Muslim Brotherhood elements. An analysis of the data suggests that the majority of these protests were not staged by members of political society but by ordinary citizens, some of whom would have predictably voted for the Muslim Brotherhood in previous elections. In most cases, citizens protested over economic issues, most notably food shortages and increases in food prices, water and fuel crises, and basic human security issues such as unsafe streets and lack of personal safety.

The mass uprisings that led to the ousting of President Morsi's regime in July 2013 occurred at a time in which the country was sitting on a volcano of continued eruption of protests. According to the Democracy Index findings, ${ }^{2}$ Egypt witnessed 14,270 protests in 2013. In view of the deeply volatile political context of the country in that year, 67 per cent of 2013's protests, or 8,999, were political. Some of these political protests against President Morsi in the first half of 2013, however, occurred post-June 2013 after the ousting of the President following a people's uprising. It is not the aim of this article to discuss whether the rupture of 30 June 2013 was a revolution or a coup. Undoubtedly the demise of the Muslim Brotherhood president was met with a wave of political protests initiated by pro-Morsi supporters. Since many of the proMorsi protests were associated with acts of violence and the article focuses on non-violent collective action, we have excluded them from analysis (Tadros 2014b).

If political protests rose in the second half of 2013, economically driven protests had a converse trend. They peaked in the first half of 2013 and waned in the second half, suggesting that bread and butter issues were among the main drivers of the June 2013 drivers. A total of 3,212 protests were organised to demand labour rights, 'especially the right to work or the rights relating to appropriate pay' for workers.

According to the report, a total of 1,052 protests were organised to claim wages, back pay, or promised demands. Yet the remainder were led by citizens that are not necessarily organised in collective entities, and who took to the street to protest daily encroachments on their rights and deteriorating conditions.

In many of the examples examined, for instance, citizens were not only asking for individual rights but a more accountable governance structure i.e. workers in the hospital pressing for an inquiry into corruption and an investigation into missing medical supplies, or citizens who block the highway as a consequence of the disappearance of a farm owner, or a young female pupil - who demand a police force that is more effective in 
dealing with crime and more responsive to their complaints.

The above protests serve as a warning sign that citizens' spontaneous organising in response to everyday hardships should not be taken lightly. Citizens' participation in protests and strikes is indicative of the existence of a mobilised social repertoire, i.e. citizens' accumulation of experience and memories of claiming entitlements and seeking accountability via some sort of public action en masse. If this repertoire is catalysed by the right constellation of factors it could potentially have a snowball effect, ${ }^{3}$ encouraging others to take part. A mobilised social repertoire, under particular conditions, could lead to a tipping over, releasing floodgates of mass citizen action. The fact that citizens are not organised and do not have a collective front may be considered by some as an obstacle to their ability to prevent cooption of citizens and plan for mass mobilisation. However, a counter-perspective is that because they are not organised in a collective form, it is more difficult for the security apparatus to identify leaders, expose plans and use coercive measures to disintegrate them.

It is impossible to predict how citizens' involvement in unruly politics will affect political outcomes due to the non-linearity of cause and effect in complex and volatile political settings where in any given instance there are several unknown, unexpected internal and external factors of influence.

\section{Alternative expressions of citizen voices}

The mass mobilisation of citizens that occurred surprised both the 'uprisers' and the many political analysts and scholars. Clearly, there was a failure to capture the 'pulse of the street' prior to the uprisings, whether in 2011 or in 2013.

After the 25 January uprising in 2011, in addition to street politics (protests, stand-ins, marches), other forms of unruly politics have emerged which provide us with a good sense of the citizen pulse on the ground. Political satire became a highly popular means of citizen engagement in 2011-12, thanks to the television programme of Bassem Youssef, El Bernameg. The programme, which had at its peak a following of an estimated five million people, mostly makes fun of the president, the Islamists and occasionally the secular forces. The show gripped millions of
Egyptians, and incurred the wrath of both the government and key leaders in the Islamist movements. What is significant is not the critique of the president or the government, but the way in which it is conveyed (through humour) and the broad-based support it has garnered. On Friday night, at the time of the broadcasting of the programme, many of Cairo's streets are empty as if a decisive football match is taking place. Whether huddled inside the coffee shops or at home, citizens are glued to their television sets. The discussions, the debates, the repetition of the most popular parts of the programme are an indicator of the pulse of the street. However, as the mood on the street changed in the aftermath of the uprising of 2013, El Bernameg's popularity among the public slumped. El-Sissi's mass popularity at that point in time (2014) meant that political satire in engaging with the president was not well placed.

Songs, poetry, street performances, dances, graffiti, and political cartoons reached new frontiers of innovation and creativity since the revolution of January 2011. While these have been cultural expressions for hundreds of years, it is how they became politicised, who politicises them at what moment that represents unruly politics. For example, one such incident involved a female pupil at a primary school in Hurghada who was supposed to recite a poem in front of the Minister of Education (known to be affiliated to the Muslim Brotherhood) visiting the premises at the time. When presenting in front of the minister, she changed the words of the poem and ended it with a highly subversive assault on Morsi (Shaban 2013). The minister apparently got up and left. These everyday acts of subversion that send powerful messages of resistance and dissent are a form of engaging politically which are indicative once again of the pulse on the ground.

This article has cautioned against two dangers that threaten to create new disconnects between what is happening on the ground and our analysis of the political situation. The first is the use of a highly reductionist approach to transitions that basically equates ballot box practices with democracy in the case of Egypt. It has argued that elections are happening simultaneously with a process of deepening authoritarianism, very much reproduced à la Mubarak. The new element is the representation of the new regime 
as being led by the devout and pious guardians of Islam. The religious element has mass appeal for large sections of the population, in particular those living in rural areas. However, even supporters of the 'unfinished transition' scenario need to be cautious of focusing exclusively on institutional and procedural mechanisms such as holding elections. The multiple voices, constituencies and platforms through which people are expressing their citizenship outside the ballot boxes are too important to ignore. If a constellation of factors leads to the outbreak of an uprising (the 'unfinished revolution' scenario), then those who have assumed an essentialist engagement with what constitutes democracy and have supported the regime, will find themselves again disconnected from the citizenry.

The second danger that threatens to reproduce the kind of disconnects that characterised many analysts' sense of citizen agency prior to the Egyptian uprisings of 2011 and 2013 is the failure to engage with unruly politics. Unruly politics is different from political sociologists' framing and conceptualisation of contentious politics. Both unruly politics and contentious politics examine forms of mobilisation outside the conventional spaces of formal citizen expression and outside the realm of conventional actors. But the major difference between the two is that contentious politics' primary concern is with organised citizen action whereas unruly politics also examines ways in which disparate citizens spontaneously coalesce around an issue even when there has been no previous organisation.

In the Egyptian case, this has taken various forms: citizens queuing for bread suddenly starting a protest, people instantly blocking the highway after the disappearance of a citizen, and so forth. Often in these instances citizens have mobilised without the mediation of organised political actors such as political parties, social movements and non-governmental organisations - in other words, the conventional political society actors.

Unruliness may take different forms, occupy different spaces and involve different actors depending on the context. However, in this article I have sought to show how spontaneous, non-formal everyday protests and strikes represent an important 'pulse of the street', and an important channel through which citizens seek accountability from the state. The failure to acknowledge and deal with the growing repertoire of citizens' expression of voice through street politics represents disengagement with the kind of unruly politics that does not feature in the conventional political society or contentious politics analysis.

We also need a better understanding of the spatial dynamics of street politics and the different forms of unruliness it assumes. We need to analyse whether there is a difference in how protests are mobilised, between the more organised incidents such as those organised by workers, women or Copts, and those more spontaneous and sporadic that cut across identity markers. The temporal dimensions of protests are also important: how long do the protests last, and what affects the decision to sustain or call them off?

An examination of the unruly politics initiated not only by organised citizens' movements but by the disorganised and spontaneous daily forms of citizens' dissent would contribute immensely to our understanding of accountability mechanisms in transition contexts, where the repertoire of revolutionary activism is still pertinent. However, some caution is needed in the interpretation of the citizen pulse: citizens' choice of expression of dissent changes according to time and circumstance. Hence, a waning of protests in Egypt in a particular year may not necessarily mean a waning of dissidence, it could also mean a shift in how citizens choose to express their voices. Second, because citizens' expression of voice is unpredictable, it is important that attempts at capturing the pulse are responsive to emerging manifestations of political agency, without presupposing a 'menu' of how they will act. Finally, the reading of the pulse has to be extremely sensitive to contextual specificity, otherwise a misinterpretation of the dynamics of citizen agency can occur. 


\section{Notes}

1 Please note that the report warns that they had only looked at the first week of December. The numbers for the rest of the month had yet to be released at the time of submission of this article (1 May 2014).

\section{Bibliography}

Abd el Wahed, W. (2013) 'Egypt: Against Whom Do We Rise?', Ikhwanonline, www.ikhwanonline.com/ Article.aspx?ArtID = 137323\&SecID = 393 (accessed 7 May 2013)

Abd el Wahab, A. (2012) 'The January 25 Uprisings: Through or in Spite of Civil Society?', IDS Bulletin 43.1: 71-77, http://onlinelibrary.wiley.com/doi/ 10.1111/idsb.2012.43.issue-1/issuetoc (accessed 7 May 2013)

Ahram Online (2013a) 'Egypt Pound Drops to New Low Against the Dollar', http://english.ahram.org.eg/NewsContent/3/0/ 69989/Business/0/Egypts-pound-drops-to-newlow-against-dollar.aspx (accessed 7 May 2013)

Ahram Online (2013b) 'Egypt's External Debt Rose 11.8\% in Q2 2012/13', http://english.ahram.org.eg/NewsContent/3/ 12/69606/Business/Economy/Egypts-externaldebt-rose-in-Q-CBE.aspx (accessed 7 May 2013)

Ali, K. (2012) 'Precursors of the Egyptian

Revolution', IDS Bulletin 43.1: 16-25, http://onlinelibrary.wiley.com/doi/10.1111/ idsb.2012.43.issue-1/issuetoc (accessed 7 May 2013)

Aly, B. (2012) 'In Letter to NY Times, Egypt Brotherhood's Shater Voices Sorrow for Slain US Diplomats', Ahram Online, http://english.ahram.org.eg/NewsContent/1/ 64/52873/Egypt/Politics-/In-letter-to-

NYTimes,-Egypt-Brotherhoods-Shater-vo.aspx (accessed 7 May 2013)

Brown, N. (2013) Islam and Politics in the New Egypt, The Carnegie Papers, Washington DC:

Carnegie Endowment for International Peace

Carothers, T. (2013) 'Egypt's Dismal Opposition, a Second Look', Carnegie Endowment for

International Peace (14 May), http://carnegieendowment.org/2013/05/14/ egypt-s-dismal-opposition-second-look/g3cf (accessed 24 June 2014)

CIHRS (2013) 'Ministry of Justice's NGO Draft Law: Putting an End to the Work of Givil Society', Cairo Institute for Human Rights Studies (CIHRS), www.cihrs.org/:p =6438\&lang =en (accessed 7 May 2013)
2 This section relies on the data presented in the report by Omar (2014).

3 For the snowball effect in relation to the Egyptian revolution, see Ezbawy (2012).

ECESR (Egyptian Centre for Economic and Social Rights) (2013) Social Protests in 2012, http://ecesr.com (accessed 7 May 2013)

El Galy, R.; El Maghraby, H.; El Deeb, F.; Morsal, F.; El Badry, H.; Sallah, A.; Abou Nour, M. and Makboul, M. (2013) 'Strikes Paralyze the Governorates', Al Youm al Sab'ie, www1.youm7.com/NewsPrint.asp?NewsID = 1044099 (accessed 7 May 2013)

El Masrafawy, M. (2013) 'Al Masry al Youm Documents the Ikhwanization of Morsi's Government in 8 Months', Al Masry al Youm, www.almasryalyoum.com/node/1472451 (accessed 7 May 2013)

Ezbawy, Y. (2012) 'The Role of the Youth's New Protest Movements in the January 25th Revolution', IDS Bulletin 43.1: 26-36, http://onlinelibrary.wiley.com/doi/10.1111/ idsb.2012.43.issue-1/issuetoc (accessed 7 May 2013)

Ezzat, A. (2013) 'Revolution? Coup D'Etat? The Gertain Thing is We Broke the Boxocracy', Jadaliyya, www.jadaliyya.com/pages/index/ 12948/revolution-coup-d\%25E2\%2580\%2599\% 25C3\%25A9tat-the-certain-thing-is-we-bro (accessed 1 July 2014)

Fung, A. and Wright, D. (eds) (2003) Deepening Democracy: Institutional Innovations in Empowered Participatory Governance, London: Verso

Gaventa, J. (2003) Triumph, Deficit or Contestation? Deepening the Deepening Democracy Debate, IDS Working Paper 264, Brighton: IDS

Goldberg, E. (2013) 'Whatever Happened to Egypt's Democratic Transition?', Jadaliyya, www.jadaliyya.com/pages/index/10444/whateverhappened-to-egypts-democratic-transition (accessed 7 May 2013)

Karpyak, O. (2013) 'Ukraine's Two Different Revolutions', BBC News, www.bbc.co.uk/news/ world-europe-25210230 (accessed 23 January 2014)

Kingsley, P. (2013) 'Egypt Spent £1.7 on Tear Gas amid Economic Crisis', The Guardian, www.guardian.co.uk/world/2013/feb/22/egypt17 million-teargas-economic-crisis (accessed 7 May 2013) 
Lynch, M. (2012) 'Reflections on Egypt's Latest Crisis', Foreign Policy, http://lynch.foreignpolicy.com/posts/2012/12/ 29/reflections_on_egypts_latest_crisis?wp_ login_redirect $=0($ accessed 7 May 2013)

McAdam, D.; Tarrow, S. and Tilly, C. (2001) The Dynamics of Contention, New York: Cambridge University Press

Miller, L. (2012) 'How Does the Arab Spring Compare to Third Wave Transitions?', Digest, www.demdigest.net/blog/2012/07/how-doesarab-spring-compare-to-third-wave-transitions/ (accessed 7 May 2013)

O'Donnell, G. (2010) Democracy, Agency and the State, Oxford and New York: Oxford University of America Press

Omar, A. (2014) 'Democracy Index Releases Report on 2013 Protests', Daily Newes Egypt, www.dailynewsegypt.com/2014/05/19/ democracy-index-releases-report-2013-protests/ (accessed 3 July 2014)

Ottaway, M. (2013) 'The Unfinished Egyptian Transition', The National Interest, http://nationalinterest.org/commentary/egyptsimmature-revolution-8013 ?page $=$ show (accessed 7 May 2013)

Sadiki, L. (2012) Rethinking Arab Democratization, Elections without Democracy, New York: Oxford University Press

Shaban, T. (2013) 'A 5th Grade Primary Student Surprises Ghoneim with Her Poems', Al Watan, www.elwatannews.com/news/details/172620 (accessed 7 May 2013)

Stepan, A. (2012) 'The Recurrent Temptation to Abdicate to the Military in Egypt', Freedom
House, www.freedomhouse.org/blog/twoperspectives-egypt's-transition (accessed 7 May 2013)

Tadros, M. (2014a) Taking Egypt's Electoral Pulse: An Analysis of Voter Preferences Prior to May 2014 Elections, Report, IDS, www.ids.ac.uk/files/ dmfile/TakingEgyptselectoralpulse-FINAL.pdf (accessed 1 July 2014)

Tadros, M (2014b) Settling After the Revolts? Egypt's Political Settlements and Violent Transition, IDS Evidence Report 57, www.ids.ac.uk/ publication/settling-after-the-revolts-egypt-spolitical-settlements-and-violent-transition (accessed 1 July 2014)

Tadros, M. (2013) 'Unfinished Transition or Unfinished Revolution? Unruly Politics and Capturing the Pulses of the Street', grey literature, www.ids.ac.uk/publication/egypt-sunfinished-transition-or-unfinishedrevolution-unruly-politics-and-capturing-thepulses-of-the-street (accessed 16 July 2014)

Tadros, M. (2012a) 'Introduction: The Pulse of the Arab Revolt', IDS Bulletin 43.1: 1-15, http://onlinelibrary.wiley.com/doi/10.1111/ idsb.2012.43.issue-1/issuetoc (accessed 7 May 2013)

Tadros, M. (2012b) The Muslim Brotherhood in Contemporary Egypt: Democracy Redefined or Confined?, London: Routledge

Wardany, Y. (2012) 'The Mubarak Regime's Failed Youth Policies and the January Uprising', IDS Bulletin 43.1: 37-46, http://onlinelibrary.wiley.com/doi/10.1111/ idsb.2012.43.issue-1/issuetoc (accessed 7 May 2013) 